\title{
Socio-Demographic Characteristics and Prevalence of Under Nutrition among Adult Sabars of Bankura District, West Bengal, India
}

\author{
Shilpita Bhandari ${ }^{1}$, Mihir Ghosh ${ }^{2}$ and Kaushik Bose* \\ Department of Anthropology, Vidyasagar University, Midnapore- 721 102, West Bengal, India. \\ ${ }^{*}$ Correspondence E-mail : shilpitabhandari22@gmail.com ${ }^{1}$; mihiranthvu@gmail.com ${ }^{2}$; kaushikbose@cantab.net ${ }^{*}$
}

\begin{abstract}
Nutritional status is an important index of economic growth and development. The status of nutrition of a given population has positively or negatively influenced nation's economic growth. Our study was designed to find out the relationship between socio-demographic characteristics and nutritional status among adult Sabars. The present cross-sectional study was conducted at six villages under Ranibandh block of Bankura District, West Bengal. A total 226 adults (males $=111$ and females = 115) Sabars, aged above 18 years in these village were included in the study. The mean (SD) values of age, family members, family income per month, and per-capita income were 37.32 (16.62) years, 4.63 (1.85) members, 2725.2 (1424.3) Rupees, 691.58 (545.32) Rupees, respectively. The prevalence of illiteracy was $45.0 \%$ and $82.6 \%$, respectively among males and females. There was a statistically significant (Chi-square $=39.67, \mathrm{p}<0.001$ ) difference between two sexes. Among males more than $65.8 \%$ were daily wage laborers. Among females collection of products was the main occupation $(28.7 \%)$. The frequency of use of drinking water from tube well, tap and well were $79.2 \%$, $11.1 \%$ and $4.4 \%$, respectively. The mean (SD) height, weight, mid-upper arm circumference (MUAC) and (body mass index (BMI) of the subjects were $159.88(5.93) \mathrm{cm}, 49.6(7.42) \mathrm{kg}, 28.38(7.83) \mathrm{cm}$ and $19.4(2.59) \mathrm{kg} / \mathrm{m}^{2}$, respectively, among males. The mean (SD) height, weight, MUAC and BMI among females were $1148.9(5.04) \mathrm{cm}, 40.1(5.88) \mathrm{kg}, 22.9(2.34) \mathrm{cm}$ and $18.0(2.30) \mathrm{kg} / \mathrm{m}^{2}$, respectively. All mean values were higher among men. The rates of under nutrition were higher $(60.0 \%)$ among the illiterate group than the literate group (37.0\%) based on BMI. Likewise, based on MUAC, the rates of under nutrition were higher (41.4\%) among illiterates compared to literates. The prevalence of under nutrition based on BMI and MUAC was high according to the World Health Organization (WHO) guideline, indicating critical nutritional situation. To reduce the nutritional stress among this ethnic group, immediate appropriate nutritional intervention programes should be initiated. Serious efforts are needed to increase their educational status and per-capita income.
\end{abstract}

Keywords: Sabar, BMI, MUAC, Educational Status, Nutritional Status

\section{Introduction}

The tribal population is at a higher risk of under-nutrition, because of the socio-cultural, socio-economic and environmental factors influencing food intake and health seeking behavior (Basu et al. 1990 and Rao et al. 2015).The health problems of any community are influenced by interplay of various factors including social, economic, biological and political ones. Nutritional status of a population is an important tool to study health of any population. Nutritional status of the population largely depends on the consumption of food in 
relation to the need and requirement. Some studies have shown a relationship between the tribal eco-system and their nutritional status (Rao \& Rao 1994; Tiwari 2007). The basic problem of the tribal people is poverty. The problems of low standard of living, hunger, starvation, malnutrition, illiteracy, disease, poor sanitary and housing facilities, etc. are serious compared to the non-tribals (Vasudevachary 2006). The quality of human resource of any country is largely determined by the quality of its economic development which in turn is a reflection of health and nutritional status.

Health status is an important index of economic growth and development. The status of health of a given population has positively or negatively influenced nation's economic growth. Indicators of health are dependent on other factors like per capita income, nutrition, sanitation, safe drinking water, social infrastructure, medical care facilities, employment status, poverty, etc which affect the health of every individual. There is direct relationship between health and development (Sharma 2012). Generally, at household level, cultural norms and practices and socioeconomic factors determine the extent of health problems among tribals. Their misery is compounded by poverty, illiteracy, ignorance of causes of diseases, hostile environment, poor sanitation, lack of safe drinking water and blind beliefs, etc. Some of the preventable diseases such as tuberculosis, malaria, gastroenteritis, measles, tetanus, whooping cough, skin diseases (scabies), etc. are also high among the tribals. The situation in India is not only different but often very complex due to regional disparities and rural-urban divide. Despite rapid strides in socio-economic development, health and education, the widening economic, regional and gender disparities are posing challenges for the health sector (Das 2012). Nutrition is one area in which traditional lifestyle of tribals and their lack of awareness plays a major role.

The Sabars (also Shabar and Saora) are one of the scheduled tribes in India who live mainly in Jharkhand, Chhattisgarh, Madhya

Pradesh, Odisha and West Bengal. During the British Raj, they were classed as one of the 'criminal tribes' under criminal tribes' act 1871, and still suffer from social stigma and ostracism in modern times. They are also known as Saora. The Sabar tribe finds mention in the Hindu epic Mahabharata, while in some parts of East Singhbhum district, mainly in Musabani, they are known as Kariya. According to 2001 census, the total population of Sabars in West Bengal was 43,599 . Sabars are the $10^{\text {th }}$ largest group in West Bengal, comprising $1.0 \%$ of the total tribal population. In our study, an attempt was made to assess the socio-economic and nutritional status of the adult Sabar tribal population who lived at Ranibandh Block of Bankura District, West Bengal.

\section{Materials and Methods}

\section{Study area}

The present cross-sectional study was conducted from six villages (Bethuala, Maula, Kotro, Botdanga, Sagardanga, Katiyam) under Ranibandh block of Bankura district of West Bengal during March 2017.

According to the 2011 census, Bankura district has a population of $3,596,292$, roughly equal to the nation of Lithuania or the US state of Connecticut. This gives it a ranking of 80th in India (out of a total of 640). The district has a population density of 523 inhabitants per square kilometer $\left(1,350 / \mathrm{m}^{2}\right)$. Its population growth rate over the decade 2001-2011 was $12.64 \%$. Bankura has a sex ratio of 954 females for every 1000 males and a literacy rate of $70.95 \%$.

Ranibandh CD Block has an area of $428.51 \mathrm{~km}^{2}$. Ranibandh is located at $22^{\circ} 51^{\prime} 50^{\prime \prime} \mathrm{N} 86^{\circ} 47^{\prime} 05^{\prime \prime} \mathrm{E}$. Ranibandh CD Block is located in the south-western part of the district. Ranibandh CD Block is bounded by Khatra and Hirbandh CD Blocks on the north, Raipur on the east, Binpur II CD Block, in Paschim Medinipur district, on the south and Manbazar I, Manbazarll and Bandwan CD Blocks, in Purulia district, on the west. It is located $41 \mathrm{~km}$ from Bankura, the district headquarters.

Ranibandh block is located approximately 233 $\mathrm{km}$ from Kolkata, the state capital of West Bengal. 


\section{The participants}

The participants were selected from six villages (Bethuala, Maula, Kotro, Botdanga, Sagardanga, Katiyam) under Ranibandh block of Bankura district of West Bengal. A total of 226 adult (males $=111$ and females $=115$ ) Sabar tribal people, aged above 18 years in those village areas were included in the study. The vast majority of the subjects were illiterate and very low-waged manual labourers belonging to low socio-economic status. Ethical considerations were guided by the Helsinki declaration (Goodyear et al., 2007). The district level and relevant local administrative authorities and community leaders were informed about the objective of the present study. Verbal informed consent was obtained from each participant in their own language prior to each interview and measurement procedure.

\section{Anthropometric measurements}

Anthropometric measurements of height $(\mathrm{cm})$, MUAC $(\mathrm{cm})$ and weight $(\mathrm{kg})$ of each subject were measured by one investigator (SB), following the standard techniques of Lohman et al. (1988). Both height and circumference were recorded to the nearest $1 \mathrm{~mm}$ and weight to nearest $500 \mathrm{~g}$.

\section{Assessment of Nutritional Status}

BMI was computed as weight $(\mathrm{kg}) /$ height $\left(\mathrm{m}^{2}\right)$. Nutritional status was evaluated using internationally accepted BMI guidelines (WHO 1995) as follows:

- CED III $: B M I<16.00 \mathrm{~kg} / \mathrm{m}^{2}$

- CED II $\quad$ :BMI $=16.0-16.9 \mathrm{~kg} / \mathrm{m}^{2}$

- CED I :BMI $=17.0-18.4 \mathrm{~kg} / \mathrm{m}^{2}$

- Normal $: \mathrm{BMI}=18.5-24.9 \mathrm{~kg} / \mathrm{m}^{2}$

- Overweight : $\mathrm{BMI}=25.0-29.9 \mathrm{~kg} / \mathrm{m}^{2}$

We followed the World Health Organization's classification (1995) of the public health problem of low BMI, based on adult populations worldwide. This classification categorizes prevalence according to percentage of a population with $\mathrm{BMI}<18.5$ $\mathrm{kg} / \mathrm{m}^{2}$

- Low (5 - 9\%): warning sign, monitoring required.

- Medium (10 - 19\%): poor situation.

- High (20 - 39\%): serious situation.

- Very high ( $\geq 40 \%)$ : critical situation.

The MUAC can be used for evaluating nutritional status studies among third world adults. The following cut-off points were used:

\begin{tabular}{|l|l|l|}
\hline $\begin{array}{l}\text { Nutritional } \\
\text { status }\end{array}$ & Among men & $\begin{array}{l}\text { Among } \\
\text { women }\end{array}$ \\
\hline $\begin{array}{l}\text { Under- } \\
\text { nutrition }\end{array}$ & $\begin{array}{l}\text { MUAC }<23.0 \\
\mathrm{~cm}\end{array}$ & $\begin{array}{l}\text { MUAC }<22.0 \\
\mathrm{~cm}\end{array}$ \\
\hline Normal & $\begin{array}{l}\text { MUAC } \geq 23.0 \\
\mathrm{~cm}\end{array}$ & $\begin{array}{l}\text { MUAC } \geq 22.0 \\
\mathrm{~cm}\end{array}$ \\
\hline
\end{tabular}

\section{Statistical analysis}

After collecting data, analysis was done using SPSS (Version 16.00) software. Descriptive statistics was performed to find the mean value, $S D$, maximum value, minimum value and percentiles. Student's $t$-test was performed to determine sex differences in mean height, weight, MUAC and BMI. Chisquare test was performed to determine the association between two discrete variables. Level of significance was set at $p<0.05$.

\section{Results:}

Table 1 shows the socio-demographic characteristics of the studied population. It presents the mean (SD) value of age, family members, family income per month, and percapita income which were 37.32 (16.62) years, 4.63 (1.85) members, 2725.2 (1424.3) Rupees and 691.58 (545.32) Rupees, respectively.

Table 1: Socio-Demographic Characteristics of the Studied Population

\begin{tabular}{|c|c|c|c|c|c|c|c|}
\hline \multirow[t]{2}{*}{ Variable } & \multirow{2}{*}{$\begin{array}{l}\text { Mean } \\
(\mathrm{N}=226)\end{array}$} & \multirow{2}{*}{$\begin{array}{l}\text { Standard } \\
\text { deviation }\end{array}$} & \multirow[t]{2}{*}{ Minimum } & \multirow[t]{2}{*}{ Maximum } & \multicolumn{3}{|c|}{ Percentiles } \\
\hline & & & & & 25 & 50 & 75 \\
\hline Age (year's) & 37.32 & 16.62 & 18 & 100 & 23.75 & 31.50 & 50.0 \\
\hline Family member & 4.63 & 1.85 & 1 & 12 & 3.0 & 4.50 & 5.0 \\
\hline Family income/ month (Rs.) & 2725.2 & 1424.3 & 300 & 12000 & 1500.0 & 3000.0 & 3900.0 \\
\hline Per capita income (Rs.) & 691.58 & 545.32 & 66.67 & 5000.0 & 364.58 & 600.0 & 900.0 \\
\hline
\end{tabular}


Int J Adv Life Sci Res. Volume 2(1)01-10

\section{Figure 1: The studied area}
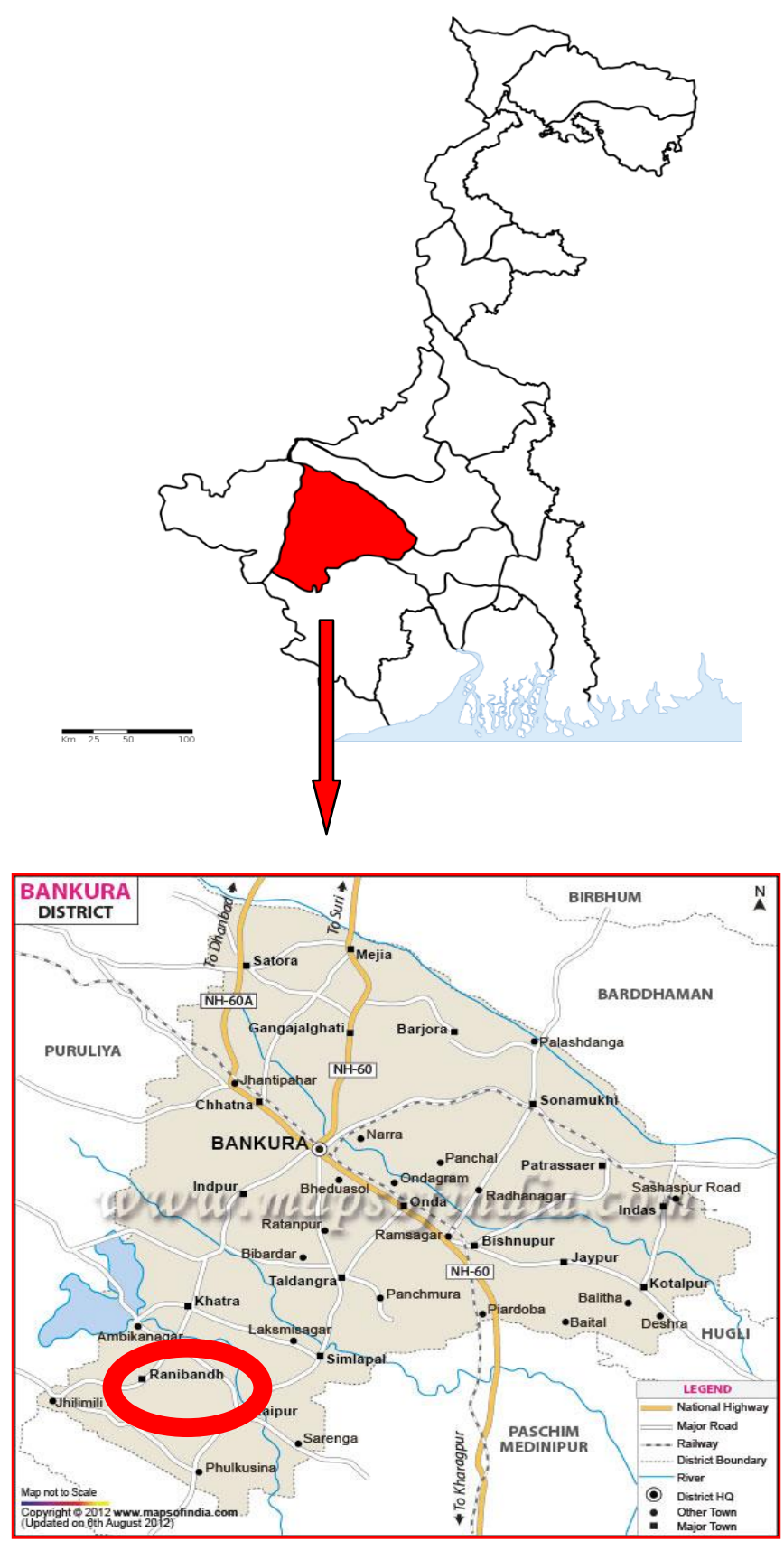

Table 2: Educational Status of the Participants

\begin{tabular}{|l|l|l|l|l|l|l|l|}
\hline Category & \multicolumn{3}{|l|}{ Educational Status } & Total \\
\cline { 2 - 7 } & Illiterate & Can sign & Primary & $\begin{array}{l}\text { Upper } \\
\text { primary }\end{array}$ & Secondary & $\begin{array}{l}\text { H.S\& } \\
\text { above }\end{array}$ & \\
\hline Male & $50(45.0 \%)$ & $35(31.5 \%)$ & $15(13.5 \%)$ & $9(8.1 \%)$ & $1(0.9 \%)$ & $1(0.9 \%)$ & 111 \\
\hline Female & $95(82.6 \%)$ & $11(9.6 \%)$ & $7(6.1 \%)$ & $0(0 \%)$ & $2(1.7 \%)$ & $0(0 \%)$ & 115 \\
\hline Combined sex & $14564.2 \%)$ & $46(20.4 \%)$ & $22(9.7 \%)$ & $9(4.0 \%)$ & $3(1.3 \%)$ & $1(0.4 \%)$ & 226 \\
\hline
\end{tabular}

Chi-square $=39.67, \mathrm{df}=5, \mathrm{p}<0.001$

Table 2 outlines the sex wise educational status of the participants. In case of males, 50 were $(45.0 \%)$ illiterates, 35 (31.5\%) could sign,
$15(13.5 \%)$ had passed out from primary school, $9(8.1 \%)$ from upper primary, $1(0.9 \%)$ 
from secondary and 1 (0.9\%) was higher secondary and above.

Figure 2: Educational Status of the participants

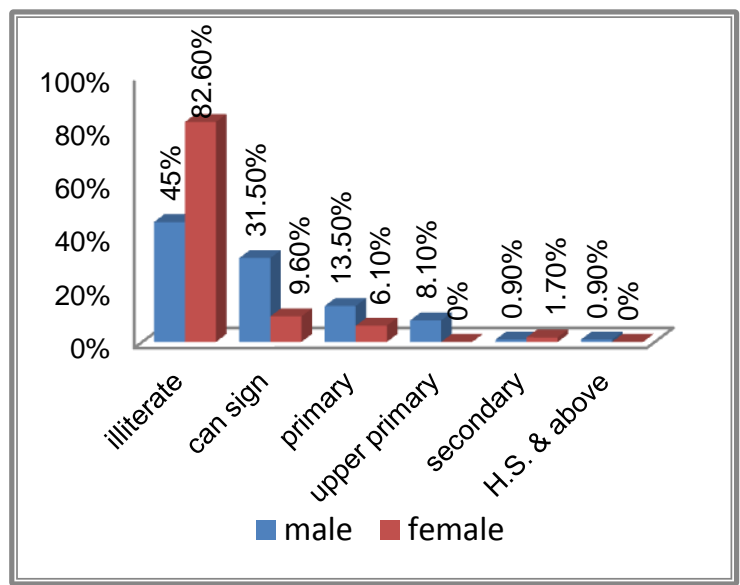

In case of females, $95(82.6 \%)$ were illiterates, $11(9.6 \%)$ could sign, $7(6.1 \%)$ had passed out from primary school and 2 (1.7\%) from secondary school. There was a significant sex difference.

Table 3 shows the sex wise occupational status of the participants. In case of males, 23 (20.7\%) were unemployed, 12 (10.8\%) were agriculturalists, $73(65.8 \%)$ were daily wage labourers, $1(0.9 \%)$ were government officers while $2(1.8 \%)$ collected forest products. In case of females, 61 (53.0\%) were unemployed, $1(0.9 \%)$ was in private service and $33(28.7 \%)$ were collecting forest products. No women were involved in agricultural work. There was a significant sex difference.

Table 3: Occupational Status of the Studied Population

\begin{tabular}{|c|c|c|c|c|c|c|c|}
\hline \multirow[t]{2}{*}{ Category } & \multicolumn{6}{|c|}{ Occupation Category } & \multirow[t]{2}{*}{ Total } \\
\hline & $\begin{array}{l}\text { Not } \\
\text { applicable }\end{array}$ & Agriculture & $\begin{array}{l}\text { Daily wage } \\
\text { labour }\end{array}$ & $\begin{array}{l}\text { Govt. } \\
\text { service }\end{array}$ & $\begin{array}{l}\text { Pvt. } \\
\text { service }\end{array}$ & $\begin{array}{l}\text { Collection } \\
\text { of the } \\
\text { forest } \\
\text { products }\end{array}$ & \\
\hline Male & $23(20.7 \%)$ & $12(10.8 \%)$ & $73(65.8 \%)$ & $1(0.9 \%)$ & 0 & $2(1.8 \%)$ & 111 \\
\hline Female & $61(53.0 \%)$ & 0 & $20(17.4 \%)$ & 0 & $1(0.9 \%)$ & $33(28.7 \%)$ & 115 \\
\hline Combined Sex & $84(37.2 \%)$ & $12(5.3 \%)$ & $93(41.2 \%)$ & $1(0.4 \%)$ & $1(0.4 \%)$ & $35(15.5 \%)$ & 226 \\
\hline
\end{tabular}

Chi-square $=88.80, \mathrm{df}=5, \mathrm{p}<0.001$

Figure 3: Occupational status

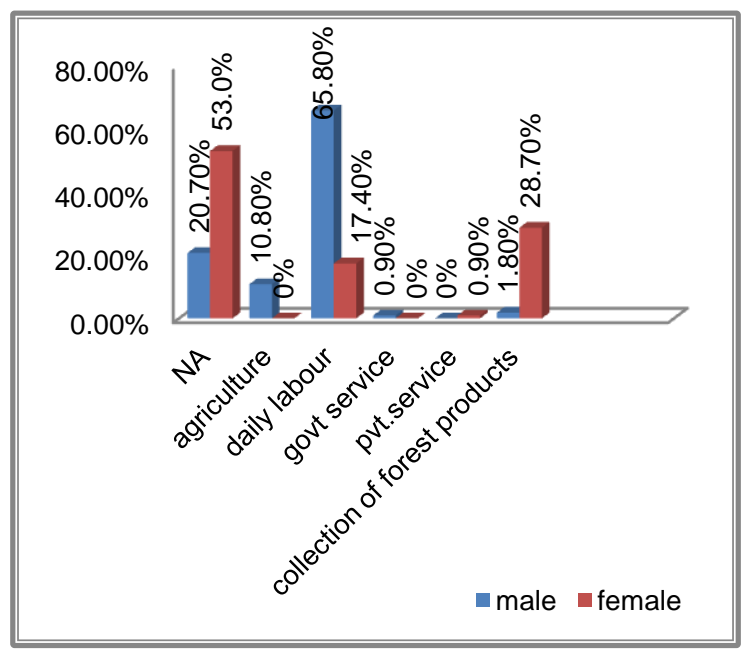

Table 4 shows the sources of drinking water of the studied population. Overall, $79.2 \%$ persons had access to tube well water, $11.1 \%$ used tap water and $4.4 \%$ drank water from well.
Table 4: Sources of Drinking Water

\begin{tabular}{|l|c|c|}
\hline $\begin{array}{l}\text { Sources of } \\
\text { drinking } \\
\text { water }\end{array}$ & Frequency & Percentage (\%) \\
\hline Tube well & 179 & 79.2 \\
\hline Tap water & 25 & 11.1 \\
\hline Well & 10 & 4.4 \\
\hline Others & 12 & 5.3 \\
\hline
\end{tabular}

Figure 4: Sources of drinking water

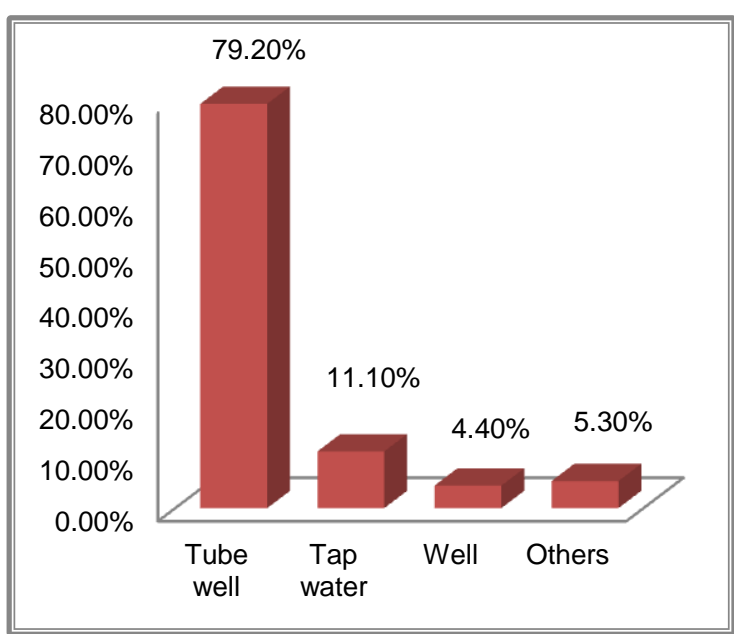


Table 5 presents the mean (SD) values of height, weight, MUAC and BMI. The mean value of height, weight, MUAC and BMI were higher among males 159.9 (5.9) cm, 49.7 (7.4) $\mathrm{kg}, 25.2(3.9) \mathrm{cm}$, and $19.4(2.6) \mathrm{kg} / \mathrm{m}^{2}$ respectively than females $\{148.9(5.4) \mathrm{cm}$, $40.1(5.9) \mathrm{cm}, 22.9(2.3) \mathrm{cm}$, and 18.1 (2.3) $\left.\mathrm{kg} / \mathrm{m}^{2}\right\}$. There were statistical significant differences $(p<0.001)$ between the sexes.

Table 5: Anthropometric Characteristics

\begin{tabular}{|l|l|l|l|l|l|}
\hline \multirow{2}{*}{ Variables } & \multicolumn{2}{|l|}{$\begin{array}{l}\text { Male } \\
(\mathbf{n}=111)\end{array}$} & \multicolumn{2}{|l|}{$\begin{array}{l}\text { Female } \\
(\mathbf{n}=115)\end{array}$} & 't' value \\
\cline { 2 - 5 } & Mean & SD & Mean & SD & \\
\hline $\begin{array}{l}\text { Weight } \\
(\mathrm{kg})\end{array}$ & 49.6 & 7.42 & 40.12 & 5.88 & $10.760^{*}$ \\
\hline $\begin{array}{l}\text { Height } \\
(\mathrm{cm})\end{array}$ & 159.88 & 5.93 & 148.99 & 5.04 & $14.880^{\star}$ \\
\hline $\begin{array}{l}\text { MUAC } \\
(\mathrm{cm})\end{array}$ & 25.24 & 3.89 & 22.86 & 2.34 & $5.576^{*}$ \\
\hline $\begin{array}{l}\mathrm{BMl} \\
\left(\mathrm{kg} / \mathrm{m}^{2}\right)\end{array}$ & 19.43 & $\begin{array}{l}2.5 \\
9\end{array}$ & 18.04 & 2.3 & $4.235^{\star}$ \\
\hline
\end{tabular}

${ }^{*} p<0.001$

Figure 5: Relationship Between Educational Status and Nutritional Status Based on BMI

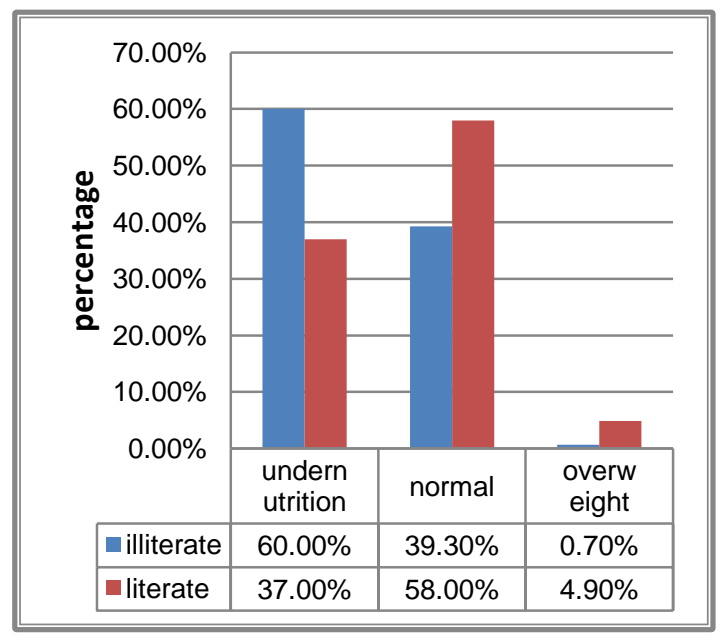

Table 6 outlines the relationship between educational status and nutritional status based on BMI. We found a strong relationship between education and nutritional status. Among illiterates, $60.0 \%$ belonged to the under-nutrition group, $39.3 \%$ were normal and $0.7 \%$ were overweight. On the other hand among literates $37.0 \%$ were categorized as under-nutrition, $58.0 \%$ were normal while
$4.90 \%$ were overweight. Educational status was significantly associated with nutritional status.

Table 6: Relationship between Educational

Status and Nutritional Status based on BMI

\begin{tabular}{|c|c|c|c|c|}
\hline \multirow{2}{*}{$\begin{array}{c}\text { Educatio } \\
\text { nal } \\
\text { Category }\end{array}$} & \multicolumn{3}{|c|}{ Nutritional Status Based on } & Total \\
\cline { 2 - 4 } & $\begin{array}{c}\text { Under } \\
\text { nutrition } \\
(\%)\end{array}$ & $\begin{array}{c}\text { Normal } \\
(\%)\end{array}$ & $\begin{array}{c}\text { Over } \\
\text { weight } \\
(\%)\end{array}$ & \\
\hline Illiterate & $\begin{array}{c}87 \\
(60.0 \%)\end{array}$ & $\begin{array}{c}57 \\
(39.3 \%)\end{array}$ & $\begin{array}{c}1 \\
(0.7 \%)\end{array}$ & 145 \\
\hline Literate & $\begin{array}{c}30 \\
(37.0 \%)\end{array}$ & $\begin{array}{c}47 \\
(58.0 \%)\end{array}$ & $\begin{array}{c}4 \\
(4.9 \%)\end{array}$ & 81 \\
\hline Total & $\begin{array}{c}117 \\
(51.8 \%)\end{array}$ & $\begin{array}{c}104 \\
(46.0 \%)\end{array}$ & $\begin{array}{c}5 \\
(2.2 \%)\end{array}$ & 226 \\
\hline
\end{tabular}

chi-square $=13.48, \mathrm{df}=2, \mathrm{p}<0.001$

Figure 6: Relationship between Educational Status and Nutritional Status based on MUAC

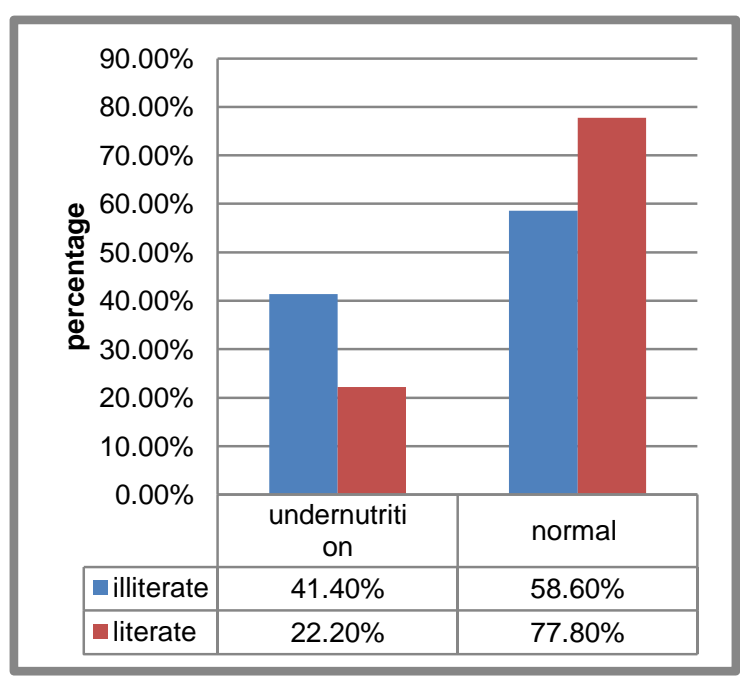

Table 7 highlights the relationship between educational status and nutritional status based on MUAC. Here also there was a strong relationship between education and nutrition. Among illiterates $41.4 \%$ belonged to the under-nutrition group while $58.6 \%$ were normal. On the other hand among literates, $22.2 \%$ belonged to the under-nutrition group while $77.8 \%$ were normal. Here also there was a significant association between educational status and nutritional status. 
Table 7: Relationship between Educational Status and Nutritional Status based on MUAC

\begin{tabular}{|c|c|c|c|}
\hline \multirow{2}{*}{ Educational Category } & \multicolumn{2}{|c|}{ MUAC Category } & \multirow{2}{*}{ Total } \\
\cline { 2 - 3 } & Under nutrition & Normal & \\
\hline Illiterate & $60(41.4 \%)$ & $85(58.6 \%)$ & 145 \\
\hline Literate & $18(22.2 \%)$ & $63(77.8 \%)$ & 81 \\
\hline Total & $78(34.5 \%)$ & $148(65.5 \%)$ & 226 \\
\hline
\end{tabular}

Chi-square $=8.43, \mathrm{df}=1, \mathrm{p}<0.01$

Table 8: Comparison of mean BMI $\mathrm{kg} / \mathrm{m}^{2}$ and prevalence of CED among the various tribal population of India

\begin{tabular}{|c|c|c|c|c|c|c|}
\hline \multirow[t]{2}{*}{ Community } & \multicolumn{2}{|c|}{ Mean BMI $\left(\mathrm{kg} / \mathrm{m}^{2}\right)$} & \multicolumn{2}{|c|}{ CED Prevalence (\%) } & \multirow{2}{*}{$\begin{array}{l}\text { Study area } \\
\text { (State) }\end{array}$} & \multirow[t]{2}{*}{ Reference } \\
\hline & Male & Female & Male & Female & & \\
\hline Santal & 20.5 & 19.5 & 30.5 & 38.5 & West Bengal & Mukhopadhyay 2010 \\
\hline Santal & 19.5 & 18.1 & 55.0 & 52.5 & West Bengal & Das \& Bose 2010 \\
\hline Munda & 19.35 & --- & 35.8 & --- & West Bengal & Bose et al. 2011 \\
\hline Oraon & 19.46 & --- & 37.5 & --- & West Bengal & Bose et al. 2011 \\
\hline Birhor & 20.5 & 20.2 & 19.4 & 33.3 & West Bengal & Das et al. 2013 \\
\hline Bhumij & 18.6 & --- & 52.3 & ---- & West Bengal & Ghosh \& Bose 2015 \\
\hline Mahali & 19.9 & 17.9 & 42.2 & 63.6 & West Bengal & Ghosh \& Bose 2017 \\
\hline Savara & 18.5 & --- & 53.0 & --- & Orissa & Chakrabarty et al, 2008 \\
\hline Oraon & 18.8 & 19.3 & 47.0 & 30.7 & Orissa & Beck \& Mishra, 2010 \\
\hline Savar & 18.9 & 19.3 & 38.0 & 49.0 & Orissa & Bisai \& Bose, 2012 \\
\hline Oraon & 18.0 & $\begin{array}{ll}-- \\
-\end{array}$ & 53.1 & $\begin{array}{ll}-- \\
-\end{array}$ & Jharkhand & Chakraborty \& Bose, 2008 \\
\hline Mannan & 20.2 & 19.1 & 23.1 & 52.2 & Kerala & John \& Ramadas, 2008 \\
\hline Jarwa & 18.9 & 19.8 & 5.5 & --- & $\begin{array}{l}\text { Andaman \& } \\
\text { Nicobar Island }\end{array}$ & Sahani, 2004 \\
\hline Onge & 19.7 & 21.2 & 12.9 & 29.2 & $\begin{array}{l}\text { Andaman \& } \\
\text { Nicobar Island }\end{array}$ & Rao et al, 2006 \\
\hline Mech & 20.5 & --- & 6.0 & --- & Assam & Khongsdier, 2001 \\
\hline Miris & 19.6 & --- & 34.0 & --- & Assam & Khongsdier, 2001 \\
\hline Pnars Khasis & 19.9 & --- & 14.3 & --- & Meghalaya & Khongsdier, 2001 \\
\hline War Khasis & 20.1 & --- & 35.0 & $\begin{array}{ll}--- \\
\end{array}$ & Meghalaya & Khongsdier, 2002 \\
\hline Tangkhul Naga & --- & 21.2 & --- & 16.2 & Manipur & Mungreiphy et al, 2012 \\
\hline Bhotias & 19.5 & --- & 45.3 & $\begin{array}{ll}--- \\
\end{array}$ & Uttarakhand & Kapoor et al, 2012 \\
\hline Sabar & 19.4 & 18.0 & 52.0 & 65.0 & West Bengal & Present study \\
\hline
\end{tabular}

\section{Discussion}

The health and nutrition problems of the vast tribal population of India are as varied as the tribal groups themselves who present a bewildering diversity and variety in their socioeconomic, socio-cultural and ecological settings. The level of malnutrition is high among the tribal population (Deka 2011). Numerous studies have already been done on their socio-economic and nutritional status. From the outcomes, it is evident that there is a strong relationship between them. Nutritional status of the Garo people of Mymensingh district represents a gloomy picture. Underweight, normal, overweight and obesity levels were $30 \%, 46 \%, 16 \%$ and $8 \%$, respectively. Low level of income as well as illiteracy may be the reason behind that situation (Naser 2015). Tribal people are particularly vulnerable to malnutrition due to their traditional socio-cultural practices and low literacy level. In another study, the low socioeconomic status of Saharia is quite apparent from their income and educational level. The impact of low socio-economic status is clearly evident in the prevalence of CED among males (48.8\%) and females (37.2\%). A higher prevalence of CED as well as overweight among males in comparison to females reflects the higher sensitivity in terms of BMI to their environment. It was also observed that the level of undernutrition on the basis of MUAC was higher among Saharia females (Kapoor et al. 2009). In the present study, we also found a relationship between socio- 
economic status and nutritional status. Most of the men were engaged in daily wage labour $(65.8 \%)$ while women were mainly collectors of forest products $(28.7 \%)$. While some males $(10.80 \%)$ undertook agricultural work none of the women did. There was a significant sex difference. In present study we also found that females were more undernourished than males.

In general, the literacy rate of tribal population in India as well as in West Bengal is very poor. Dropping out of school is very common among the tribal population. Many tribal schools have high dropout rates. Children attend for the first three to four years of primary school only to lapse into illiteracy later. Few who enter continue up to the tenth grade; of those who do, few manage to finish high school. Therefore, very few are eligible to attend institutions of higher education, where the high rate of attrition continues. Eldest members of tribes often are loath to send their children to school, needing them, they say, to work in the fields (Thirumani and Sindhuja 2015). In a study comparing the educational status of males and females, Bhaina tribals of Bilaspur, Chhattisgarh, showed a significant difference in distribution of educational status $(p<$ 0.0001 ). More than $30 \%$ of the studied population was observed to be illiterate (males $=17.7 \%$ and females $=42.9 \%$ ). Proportion of female population goes on decreasing when moving towards higher educational status (Singh et al. 2014). Among the tribal women (Gujjar and Bakerwal) of Kashmir, 52.6\% of the respondents were literate. (Hamid and Vaida 2017). The present study among the Sabar tribe of Bankura district substantiates this fact. Females (82.6\%) were more illiterate than males $(45.0 \%)$. This difference was statistically significant $(p<0.001)$. We also found a strong statistically significant relationship between educational status and nutritional status (both BMI and MUAC), illiterates were more undernourished than literates.

In case of education a recent study has been done on three different tribal communities Kolha, Bhumija and Bathudis of Odisha (Behera 2017). Here the author found that male literacy rate was higher than females.
Among these three tribal communities, literacy rate was highest among Bathudi households followed by Kolha and the lowest was in Bhumija households. Moreover, the literacy of tribal households were lower than the average literacy rate of district, state and national average as per 2011 census.

Apart from these socio-cultural obstacles, the religion, education and economic factors do alter the food behaviours (Sarkar 2016). Simultaneously, the source of water plays an important role in influencing nutrition status. Malnourishment may not contribute to death directly but diseases like diarrhoea, measles, malaria and pneumonia are often the cause death of malnourished people. The intergenerational cycle of undernutrition is concomitant with high incidence of babies born with low birth weight $(22 \%)$ resulting in more susceptibility to infections. While overall picture of undernutrition is shockingly high, the status is further exacerbated by the significant inequalities across states and socioeconomic groups - girls, rural areas, the poorest and scheduled tribes and castes are the worst affected and these inequalities appear to be increasing (Shinde and Patil 2016). The role of the WHO Guidelines for Drinking Water Quality accents an integrated approach to water quality assessment and management from source to consumer. It emphasizes on quality preservation and prevention of contamination and confers to be proactive and participatory, and address the needs of those in developing countries who have no access to piped community water supplies. The guidelines emphasize the protection of microbial quality to obstruct waterborne infectious disease as an essential goal. In addition, they address protection from chemical toxicants and other pollutants (Sarkar 2016). In our study, most of the villagers $(79.20 \%)$ access tube well water as their source of drinking water while $11.1 \%$ used tap water and $4.4 \%$ drank water from well.

Umpteen studies have already been done by many researchers on health and nutritional status of tribal population of different regions of India, related with anthropometry. Table 8 demonstrates the comparison of mean BMI 
$\mathrm{kg} / \mathrm{m}^{2}$ and prevalence of CED (\%) among several tribal population of India. This table represents that, the mean BMI was higher among Santals, Birhors of West Bengal and Mech of Assam, in case of males. In case of females, mean BMI was higher among Birhors of West Bengal, Onges of Andaman \& Nicobar Island and Tangkhul Nagas of Manipur.

According to the WHO guideline, percentage of prevalence of CED was very high ( $\geq 40 \%)$ among Santals (Das \& Bose 2010), Bhumijs (Ghosh \& Bose 2015), Mahalis (Ghosh \& Bose 2017) of West Bengal, Savaras (Chakrabarty et al, 2008), Oraons (Beck \& Mishra, 2010) of Orissa, Oraons (Chakraborty \& Bose, 2008) of Jharkhand and Bhotias (Kapoor et al., 2012) of Uttarakhand, in case of males. On the other hand in case of females, we found that percentage of prevalence of CED was very high $(\geq 40 \%$ ) among Santals (Das \& Bose 2010), Mahalis (Ghosh \& Bose 2017) of West Bengal, Savaras (Chakrabarty et al, 2008) of Orissa and Mannans (John \& Ramadas, 2008) of Kerala. Sabars females of present study, was also belonged to the critical situation according to this guideline. Thus, these numerous studies clearly showed that, in general, the percentage prevalence of CED was higher among females than males of the tribal populations.

\section{Conclusion}

In conclusion, the present study clearly showed that there is a need to identify, reorganize and reallocate resources for tribal

\section{References}

Basu, S.K., Jindal, A., Kshatriya, G.K.. (1990). The determinants of health seeking behaviour among tribal population of Bastar district, Madhya Pradesh. South Asian Anthropologist. 1, pp.1-6.

Beck, P., Mishra, B.K.. (2010). Socio-Economic Profile and Quality of Life of Selected Oraon Tribal Living in and Around Sambalpur Town, Orissa. Current Research Journal of Social Sciences. 2(6), pp. 340-349.

Behera, G. (2017). Impact of literacy status on Participation of Tribal Women in Panchayati Raj - A case study of Nilgiri ITDA Block of Balasore district in Odisha. IOSR. 22(6), pp.14-23.

Bisai, S, Bose, K. (2012). Critical nutritional stress among adult tribal populations of West Bengal and communities, based on their requirements. The design of the development programs and the health needs of the tribal population have to be identified keeping in mind their habitat and socio cultural practices. The prevalence of under nutrition based on BMI and MUAC was high according to the World Health Organization (WHO) guidelines, indicating critical nutritional situation. To reduce the nutritional stress among this ethnic group, immediate appropriate nutritional intervention programmes should be initiated. Serious efforts are needed to increase their educational status and per-capita income.

\section{Recommendation}

Thus, we suggest that similar studies be undertaken to determine the prevalence of undernutrition among Sabars of another region, as well as other ethnic groups, especially in rural areas. Those studies will help us to generate new data which can be used for comparison with the prevalence of under nutrition in the local, national and international context. There are many such nutritionally vulnerable tribal populations in India.

\section{Acknowledgements}

The authors express their sincere thanks to all the study participants. Partial financial assistance was provided by the UGC-SAP Programme of Government of India.

\section{Orissa, India. Nature Precedings hdi:10101/npre.2012.7068.1.}

Bhattacharya, K.K., Haque, M., Biswas, T.K, (2006). Nutritional status of two primitive tribes of eastern India. In: P. Dash Sharma, editor. Anthropology of Primitive Tribes of India. 323.

Bose, K., Debsharma, B., Das, S. (2011). Is body adiposity index a good measure of nutritional status? A study among two adult tribal populations of Paschim Medinipur, West Bengal, India. Science Journal of Sociology and Anthropology. 1, pp. 1-7.

Chakrabarty, S., Pal, M., Bharati, S., Bharati, P. (2008). Chronic Energy Deficiency among Tribal Communities of Orissa, India. Tribes \& Tribals. 2, pp. 95-101. 
Chakraborty, R., Bose, K. (2008). Anthropometric characteristics and nutritional status of adult Oraon men of Gumla District, Jharkhand, India. The Internet Journal of Biological Anthropology. 2(1).

Das, K. (2012). Health as an economic indicator, Kurukshetra 60 (10), pp.6.

Das, S. \& Bose, K. (2010). Body Mass Index and Chronic Energy Deficiency among adult Santal of Purulia, West Bengal, India. International Journal of Human Sciences. 7 (2).

Das, S., Mahata, M. \& Bose, K. (2013). Nutritional profile of adult Birhors of Purulia: A particularly vulnerable tribal group of West Bengal, India. Asian Academic Research Journal of Multidisciplinary; 1(5): 262-275

Deka, S. (2011). Health and Nutritional Status of the Indian Tribes of Tripura and Effects on Education. Student Pulse, 3(03).

Ghosh, M. \& Bose, K. (2015). Assessment of Nutritional Status among male Bhumij of West Bengal, India: A comparison of body mass index and mid-upper arm circumference. Human Biology Review, 4(2).

Ghosh, M. \& Bose, K. (2017). Prevalence of undernutrition among adult Mahalis of Bankura district, West Bengal. National Seminar on tribal development in West Bengal, at Cultural Research Institute; Abstract page no. 28.

Hamid, T., Vaida, N. (2017). A study on nutritional status of scheduled tribe (Gujjar and Bakerwal) women of Kashmir. International Journal of Home Science. 3(3), pp. 203-205.

James, W.P.T., Mascie-Taylor, C.G.N., Norgan, N.G., Bristrian, B.R., Shetty, P., Ferro-Luzzi, A. (1994). The value of arm circumference measurements in assessing chronic energy deficiency in Third World adults. European Journal of Clinical Nutrition. 48, pp.883-894.

John, P., Ramadas, S. (2008). Body mass index: An indicator of nutritional status among adult Mannan tribes of idukki District, Kerela. Academi Review 15(1 \& 2), pp.60-65.

Kapoor, S., Tyagi, R., Saluja, K., Chaturvedi, A. and Kapoor, A.K. (2009). Nutritional Profile and SocioEconomic Status of Saharia, a Primitive Tribe of India. The Open Anthropology Journal. 2, pp.58-63.

Kapoor, A.K., Saluja, K., Verma, D., Kapoor, S. (2012). Predictors of Hypertension among Adult Tribal Males of India. International Journal of Tropical Disease \& Health. 2(4), pp. 241-256.

Khongsdier, R. (2001). Body mass index of adult males in 12 populations of Northeast India. Annals of Human Biology. 28(4), pp.374-383.

Khongsdier, R. (2002). Body mass index and morbidity in adult males of the War Khasi in Northeast India. European Journal of Clinical Nutrition. 56(6), pp.484-489.
Lohman, T.G., Roche, A.F., Martorell, R. (1988). Anthropometric Standardization Reference Manual.Human Kinetics Books, Chicago.

Mukhopadhyay, A. (2010). Anthropometric characteristics and undernutrition among adult santal tribe of Birbhum District, West Bengal, India. Anthropological Science.118(1), pp.57-60.

Mungreiphy, N.K., Kapoor, S., Sinha, R. (2012). Relationship between nutritional status, respiratory performance and age: study among Tangkhul Naga females of Northeast India. Acta Biologica Szegediensis. 56(1), pp. 31-36.

Naser, M.A. (2015). Socioeconomic Profile and Nutritional Status of Aged Garo Ethnic People. European Academic Research. III (7), pp.80458051 .

Rao, H.D., Rao, M.K. (1994). Levels of malnutrition and socioeconomic conditions among Maria Gonds. J Hum Ecol. 5, pp.185-90.

Rao, K.M., Kumar, R.H., Krishna, S.R., Bhaskar, V., Laxmaiah, A. (2015). Diet \& nutrition profile of Chenchu population - a vulnerable tribe in Telangana \& Andhra Pradesh, India. Indian J Med Res. 141 (8), pp.688-96.

Rao, V.G., Sugunan, A.P., Murhekar, M.V., Sehgal, S.C. (2006). Malnutrition and high childhood mortality among the Onge tribe of the Andaman and Nicobar Islands. Pub Healt Nutr. 9(1), pp.19-25.

Sahani, R. (2004). Seasonal variation in nutritional status of the Jarwas. Journal of Anthropological Survey India. 53, pp. 99-117.

Sarkar, R. (2016). A Study on the Health and Nutritional Status of Tribal Women in Godam Line Village of Phansidewa Block in Darjeeling District. IOSR. 21 (11), pp.15-18.

Singh, H.S., Ghritlahre, M., Das, S. (2014). Nutritional Status among Females of Bhaina Tribe of Bilaspur, Chhattisgarh India: An Anthropological insight. Journal of Anthropology. http://dx.doi.org/10.1155/2014/897893

Sharma Pal, A. (2012). Rural Health Scenario in India. Kurukshetra. 60 (10), pp.9.

Shinde, D.N., Patil, C.L. (2016). Malnutrition and Drinking water of the children's in tribal area in India: Review. New Man. 3 (1), pp. 52-55.

Thirumani, Devi A., Sindhuja, S. (2015). Nutritional Status and Knowledge, Life Style and Dietary Practices of Tribal Adult Women. International Journal of Recent Scientific Research. 6(6), pp.4449-4452.

Vasudevachary, A.K. (2006). Tribal development in Andhra Pradesh. Kurukshetra. 54, pp. 33- 36.

World Health Organization (1995). Physical Status: The Use and Interpretation of Anthropometry.Technical Report Series No. 854. World Health Organization, Geneva. 